\title{
COMO EVOLUEM OS \\ MODELOS MENTAIS
}

A. Tarciso Borges Col. Técnico, UFMG

RESUMO: Após revisão da literatura onde se define o conceito de modelo mental, apresentamos resultados de estudo sobre os modelos mentais de eletricidade, magnetismo e eletromagnetismo de seis grupos de indivíduos. Entre estudantes e profissionais com experiências de escolarização diversificadas, foram entrevistadas 56 pessoas. As entrevistas ocorreram enquanto se realizaram experimentos com imãs, eletroímãs e circuitos elétricos simples. Foram identificados quatro modelos de eletricidade, cinco de magnetismo e três para explicar o magnetismo no eletroímã. Apresentamos os dados desse estudo centrando atenção na evolução dos modelos identificados. Em nossa análise, destacamos quais aspectos dos modelos sofrem mudanças significativas à medida que os sujeitos ganham maior compreensão conceituai e experiência com os fenômenos estudados.

\section{Introdução}

As idéias e concepções de estudantes sobre tópicos de ciências têm sido objeto de intensa investigação ao longo das últimas décadas. Vários desses estudos tiveram como objetivo investigar os modelos de eletricidade dos estudantes (Duit et ai, 1985). Entretanto, pouco foi feito com relação a magnetismo e eletromagnetismo, embora haja razões para se crer que as idéias dos estudantes sobre eles possam estar relacionadas com suas idéias sobre eletricidade (Haupt, 1952; Andersson, 1986). Este trabalho baseia-se num estudo dos modelos mentais de estudantes e adultos sobre eletricidade, magnetismo e eletromagnetismo (Borges, 1996;

1997; Borges e Gilbert, 1998), e objetiva explorar como tais modelos evoluem à medida que os sujeitos ganham maior compreensão conceituai e experiência com as áreas em questão.

O construto de modelo mental vem sendo usado em várias áreas do conhecimento humano, embora não exista clareza sobre o seu significado. O interesse em modelos e modelos mentais deve-se, em parte, à aceitação ampla da idéia de que nós só podemos apreender o novo construindo modelos dele, a partir daquilo que já conhecemos. Desse ponto de vista, explicações são tentativas de compreender um evento ou uma situação não familiar em termos de coisas com as quais estamos habituados, ou em termos de sistemas mais familiares de relações, por meio de analogias.

Os modelos usados na ciência, sejam eles teóricos ou matemáticos, são criações dos cientistas, propostos para explicar fenômenos numa dada área da ciência. Eles são submetidos à crítica, às vezes, são revisados ou ampliados, à medida que outros cientistas se engajam num processo de examinar as explicações possíveis para cada modelo. Eventualmente, alguns deles ganham aceitação e são disseminados via livros-texto e cursos. Um modelo científico supõe a existência de uma correspondência estrutural entre sistemas distintos e deve satisfazer a dois critérios: ser conceitualmente compreensível e produtivo. Constrastando com o caráter público dos modelos científicos, os modelos mentais são pessoais e só existem na mente de cada sujeito. Em ambos os casos, no entanto, o modelo é o mediador entre a realidade 
e a mente humana. Eles falam tanto de nós mesmos de nosso conhecimento prévio, de nossa experiência e forma de pensar como da realidade externa fenômenos, objetos, processos- que está sendo modelada. Sua utilidade vem justamente do fato de que ele é uma representação simplificada do sistema representado. Nesse sentido, um modelo capta apenas alguns elementos, selecionados por quem o constrói, daquilo que ele representa e, portanto, é da natureza dos modelos serem incompletos.

\section{Modelos Mentais}

Modelos e modelos mentais são correntemente empregados em diversas áreas do conhecimento, tais como em Filosofia (ver, por exemplo, Giere, 1988), na Psicologia (Mayer, 1989), no estudo de Sistemas Homem-Máquina (Rouse e Morris, 1986) , no estudo da Interação Homem-Computator (Carroll, 1991; Rogers, Rutherford \& Bibby, 1991), na Compreensão de Texto e Linguagem (Johnson-Laird, 1983) e em Educação (Mayer, 1992).

Apesar de ser utilizado há pelo menos 30 anos, não existe uma definição consensual explicita do que seja um modelo mental. O conceito de modelo mental se disseminou a partir da publicação de dois livros, ambos com o título "Mental Modeis", publicados em 1983. O primeiro deles, editado por Gentner e Stevens (1983), é uma coleção de contribuições a um seminário sobre o assunto. Nele, várias visões do conceito são apresentadas de maneira mais ou menos implícita. O segundo livro (Johnson-Laird, 1983) é um trabalho em que o autor procura explicar o raciocínio dedutivo e a compreensão de texto. As duas obras partem de pressupostos distintos e serviram para caracterizar dois tipos de modelos mentais, embora a diversidade de usos sugira que existem outras concepções de modelo mental (veja Rouse e Morris, 1986 para uma discussão).

Uma caracterização simples de um modelo mental é que ele é um modelo que existe na mente de alguém. Isso significa que não há meios de se conhecerem, objetivamente, os modelos mentais de outros. Nós só podemos falar a respeito de nossa própria concepção dos modelos mentais usados por outras pessoas. Freqüentemente, os próprios usuários não têm consciência dos modelos que utilizam. Isso não é exclusivo do estudo de modelos mentais, mas de todos os fenômenos da cognição. Intuitivamente, a idéia é simples: pensar envolve a construção e o uso de modelos simplificados da realidade. Mesmo quando somos expostos a um modelo aceito pêlos cientistas através de um livro, de uma discussão com colegas ou de uma aula, nós construímos um modelo mental daquilo que entendemos, usando nossas habilidades e competências cognitivas, culturais, lingüísticas e sociais e também os conhecimentos específicos que já temos sobre o tópico.

Embora as idéias expostas no parágrafo anterior sejam amplamente aceitas, o conceito de modelo mental não pode ser considerado como unitário. Ao contrário, diferentes limitações e pressupostos são impostos ao significado do termo pelas diversas comunidades que o empregam. Por exemplo, segundo de Kleer e Brown (1981), ao fazer previsões ou explicar o funcionamento de um sistema, cada pessoa simula, mentalmente, uma estrutura simbólica de componentes interligados. Os tipos de componentes que formam o modelo e a maneira como eles estão conectados contribuem para o resultado. Esse processo de simulação mental é que permite ao usuário falar de situações que já aconteceram, isto é, sobre o passado, e também sobre o futuro. Dessa forma, a simulação mental é que permite ao usuário fazer previsões, simulando o modelo com condições iniciais hipotéticas para inferir estados futuros do sistema. Para esses autores, o processo de criar e manipular mentalmente um modelo de um sistema envolve quatro fases:

- representar o sistema; 
- propor um modelo de como o sistema poderia funcionar, considerando a sua estrutura e composição, isto é, um modelo dos componentes do sistema e de como eles estão inter-relacionados;

- imaginar o modelo funcionando, isto é, fazer a simulação mental;

- comparar os resultados da simulação com a realidade.

Se não há acordo entre os resultados e o funcionamento real do sistema, o processo é repetido. Tal processo produz explicações baseadas em ações e efeitos observados no sistema e imaginados no modelo. Dessa forma, informações contextuais e o conhecimento de como o mundo funciona são importantes para determinar o resultado da simulação. Nessa visão, o que distingue um modelo mental de conhecimento em geral é o fato de que o modelo pode ser rodado na imaginação para produzir descrições do estado de um sistema, explicações para o seu comportamento e previsões de eventos e estados futuros.

Uma outra vertente do pensamento sobre modelos mentais é devida a Johnson-Laird (1983). Sua teoria baseia-se na idéia de que nós construímos modelos de eventos e aspectos do mundo usando processos cognitivos tácitos, e raciocinamos com esses modelos. Do ponto de vista de tal teoria, a compreensão de um dado aspecto da realidade ocorre quando se verifica acordo entre o modelo construído para explicá-lo e a parte modelada. Dessa forma, nossa habilidade em dar explicações está intimamente relacionada com nossa compreensão daquilo que é explicado e, para compreender qualquer fenômeno ou estado de coisas, precisamos ter um modelo funcional dele. A teoria de Johnson-Laird distingue três diferentes tipos de representações mentais:

- as representações proposicionais, que são cadeias de símbolos que correspondem à linguagem natural;

- os modelos mentais, que são análogos estruturais de coisas e processos que existem ou ocorrem no mundo;

- as imagens, que são os correlates perceptuais dos modelos de um ponto de vista particular.

Modelos e representações preposicionais implicam níveis distintos de representação. Os modelos representam o contexto do discurso, de um evento ou de uma situação, incluindo aí os objetos envolvidos e o conhecimento tácito que o observador usa para compreendê-los. As representações preposicionais, por sua vez, representam o sentido do discurso. Os modelos mentais são estruturalmente análogos aos processos que acontecem no mundo exterior, embora sejam incompletos e não representem, diretamente, a realidade. Eles são formados por 'tokens', isto é, receptáculos de significação, e por relações entre eles. Os modelos capacitam-nos a fazer predições e inferências, a compreender fenômenos e eventos, a atribuir causalidade aos eventos observados, a tomar decisões e controlar a execução delas.

Diferentemente do que acontece com as representações preposicionais, os modelos mentais não envolvem regras explícitas de manipulação. Johnson-Laird argumenta que nosso raciocínio se processa através da construção de modelos de eventos e estados de coisas no mundo e, então, procuramos exemplos que se ajustem a um dado modelo ou contra-exemplos que os falsifiquem. O raciocínio humano, portanto, não envolve uma lógica mental, a não ser quanto às habilidades de testar a adequação de instâncias específicas aos modelos construídos. Alguns desses modelos são adquiridos apenas através de transmissão cultural ou ensino, enquanto que outros são adquiridos da interação cotidiana com outras pessoas e com o mundo. As imagens, por sua vez, correspondem a instanciações específicas dos modelos mentais. 
Brewer (1987) sugere que os modelos do tipo que aparecem no livro de Gentner e Stevens são, na realidade, modelos de causalidade em sistemas físicos e propõe denominá-los modelos mentais causais. Segundo Brewer, esses modelos dizem respeito a conhecimento prévio do usuário de natureza genérica e são semelhantes a outros conceitos usados na Psicologia, tais como 'schema' e 'frame'. A concepção de Johnson-Laird acerca de modelo mental refere-se, ainda segundo Brewer, a tipos específicos de representações usados em um dado contexto e são úteis quando um indivíduo está lidando com situações novas. Enquanto que os modelos mentais causais dizem respeito a estruturas cognitivas genéricas e mais duradouras, os modelos mentais, na concepção de Johnson-Laird, são estruturas específicas e construídas no momento em que o usuário necessita delas, sendo depois descartadas.

A distinção entre os dois tipos de modelos é colocada novamente por meio de uma outra diferença, aquela referente à dimensão, à representação e ao conteúdo da representação. Por exemplo, Payne (1991) e Bliss (1995) argumentam que os modelos do tipo Gentner e Stevens dizem respeito ao conteúdo dos modelos dos sujeitos, enquanto que, na concepção de Johnson-Laird, modelos mentais são usados para se referirem às próprias representações. Essa distinção parece ser devida a um desejo dos cientistas em explicar o raciocínio humano em termos de estruturas gerais, mas deve ser considerada com um mínimo de cautela. É discutível se podemos isolar as formas de representação mental do conteúdo das mesmas, uma vez que nós só temos acesso às nossas próprias representações dos modelos mentais dos sujeitos com quem interagimos. Uma posição mais produtiva para a pesquisa educacional é a de buscar um referencial mais amplo que dê conta da diversidade de manifestações do pensamento humano.

A posição que adotamos é a de considerar ambas as concepções de modelo mental como complementares e não como concorrentes. Trabalhos como o de Coilins e Gentner (1987), e Hayes (1985), e de Kleer e Brown (1981), claramente localizados nos níveis internos do modelo de Payne, fornecem descrições dos mecanismos cognitivos que tornam possível o raciocínio com modelos mentais, num nível que a teoria de Johnson-Laird ainda não permitiu. O que parece distintivo acerca de um modelo mental é a possibilidade de ele ser simulado mentalmente e a ênfase dada à ontologia.

Em todas as áreas de pesquisa em modelos mentais, há a preocupação em entender o significado dos sistemas investigados para os usuários. Dependendo da área de pesquisa, tal orientação pode ser mais pragmática, envolvendo descrições genéricas, de constituição ou de propósitos, dos sistemas ou das previsões e explicações acerca do seu funcionamento (Rouse e Morris, 1986). A pesquisa em modelos mentais procura responder às seguintes questões, que descrevem e explicam o sistema/objeto estudado e seu comportamento:

- Como é o sistema? (Descrever o sistema)

- De que o sistema é formado? (Descrever a estrutura e composição do sistema)

- Como ele funciona? (Explicar como funciona)

- O que ele está fazendo? (Prever ou Explicar o estado do sistema)

- Para que ele serve? $\quad$ (Descrever o propósito do sistema)

Levando-se em conta tal classificação, pode-se dizer que "modelos mentais são os mecanismos através dos quais os humanos são capazes de gerar descrições do propósito e da forma de um sistema, explicar o funcionamento do mesmo e os seus estados observados, e prever os estados futuros" (Pouse e Morris, 1986). Uma outra definição, devida a Carroll e Olson (1988), é a de que um modelo mental é "uma estrutura rica e elaborada que reflete a compreensão do usuário do que o sistema 
contém, de como ele funciona e de por que ele funciona daquela forma. Ele pode ser imaginado como conhecimento sobre o sistema suficiente para permitir ao usuário experimentar ações mentalmente antes de executá-las".

Tais definições sugerem que:

- Um modelo mental é diferente de uma representação de informações isoladas sobre o sistema: é uma estrutura rica e elaborada.

- Um modelo mental representa diferentes tipos de informação: o que o sistema contém, como ele funciona, como é a sua estrutura e por que se comporta de uma determinada maneira. Esses aspectos estão relacionados com a ontologia dos objetos e eventos que existem ou são imaginados existir no mundo.

- Um modelo mental, para algumas pessoas pelo menos, é diferente de outras formas de conhecimento, pois ele pode ser 'rodado' com entradas exploratórias, de forma a imaginar o resultado.

- Um modelo mental envolve certo grau de sistematicidade e coerência.

A posição, adotada aqui, é a de que um modelo mental é uma forma de organizar nosso conhecimento sobre um determinado objeto, processo ou fenômeno que usamos para pensar sobre eles por meio de simulação mental. Esses modelos capacitam-nos a realizar ações inteiramente na imaginação. Isso permite-nos internalizar as representações que criamos para as coisas e os estados de coisas no mundo e processá-los como se fossem externos. Várias pesquisas têm mostrado que as inferências que um indivíduo faz sobre uma determinada questão depende dos modelos adotados. Por exemplo, o estudo de Gentner e Gentner (1983) suporta a ideia de que os modelos mentais dos estudantes sobre corrente

elétrica influenciam a maneira como eles tratam problemas envolvendo circuitos elétricos simples.

Um aspecto importante é que a habilidade de um indivíduo em explicar e prever eventos e fenômenos que acontecem à sua volta evolui à medida que ele adquire modelos mentais mais sofisticados dos domínios envolvidos (Borges, 1996). Tais modelos evoluem com o desenvolvimento psicológico e com a instrução, num processo conhecido como mudança conceituai. Há evidências de que as crianças desenvolvem representações de objetos e fenômenos naturais bem antes de estudar sobre eles na escola, e de que tais representações mudam, às vezes, dramaticamente, quando elas são expostas à ciência escolar. Numa recente análise de estudos das concepções de estudantes acerca de diversos tópicos de ciências, Driver e colaboradores(1994) apontam a existência dessa tendência na evolução das concepções dos estudantes sobre tais tópicos. Em particular, eles apontam que as concepções dos estudantes tendem a evoluir através da construção de novas entidades para a descrição de eventos e fenômenos bem como através do desenvolvimento de estratégias de raciocínio. O estudo que conduzi sobre modelos mentais de eletromagnetismo (Borges, 1996;1997) sugere a mesma idéia de progressão e identifica os aspectos que mudam à medida que os sujeito adquirem conhecimento conceituai e experiência com a área.

\section{O Estudo}

Para discutir a idéia de como os modelos mentais evoluem, vamos utilizar os resultados do estudo sobre modelos mentais de eletricidade, magnetismo e de 
eletromagnetismo (Borges, 1996). Esse estudo procurou identificar os modelos mentais de eletromagnetismo e descrever as mudanças em tais modelos à medida que os usuários adquirem conhecimento e experiência com a área. Ele envolveu seis grupos de indivíduos, entre estudantes da primeira e terceira séries do ensino médio, estudantes do terceiro ano do curso técnico em eletrônica, engenheiros elétricos, professores de física e eletricistas, num total de 56 sujeitos. Eles foram entrevistados individualmente enquanto faziam várias atividades experimentais simples envolvendo circuitos elétricos, com pilhas e lâmpadas, imãs e amostras de materiais de uso cotidiano. Inicialmente, o entrevistando fazia previsões sobre os resultados de cada atividade e explicava as razões que o levavam a esperar por tal resultado. Depois realizava o experimento e, por fim, explicava o acordo ou desacordo entre previsão e resultado. Essa seqüência de Previsão, Observação e Explicação é amplamente reconhecida como uma forma eficaz de produzir informações sobre os modelos mentais usados pêlos indivíduos (White e Gunstone, 1992).

A conversa sobre cada atividade começa com questões gerais, que procuram determinar se os sujeitos reconhecem os objetos que compõem a atividade, para que servem ou para que são usados e por que são usados da forma como o são. A seguir, são apresentadas questões que exigem maior reflexão. Essa estruturação da entrevista leva em conta os aspectos considerados relevantes num modelo mental, conforme as definições de Rouse \& Morris e de Carroll \& Olson, discutidas anteriormente. O apêndice 1 apresenta as questões usadas a respeito do eletroímã.

Neste estudo, foram identificados 4 modelos de eletricidade, 5 modelos de magnetismo e 3 modelos para explicar o surgimento de magnetismo num eletroímã, que são brevemente descritos a seguir (para discussão detalhada dos modelos veja Borges, 1996;

1997 e Borges e Gilbert, 1998). As respostas dos entrevistandos a um grupo de questões foram categorizadas, gerando um conjunto de concepções específicas de cada situação. Os modelos foram identificados a partir dos conjuntos de concepções, de forma que subsumissem as respostas dadas para as questões analisadas.

\section{1 - Modelos de Eletricidade}

Diferentemente de pesquisas anteriores (Shipstone, 1985;

Osborne, 1983) que enfatizaram a forma de conexão de componentes elétricos num circuito, aqui a preocupação é de outra ordem. Os modelos que descrevo a seguir são modelos relacionados à natureza da corrente elétrica num circuito simples.

\section{a) Eletricidade como Fluxo}

Esse modelo representa corrente elétrica como "eletricidade" que flui através dos fios de um circuito. Termos como "energia", "corrente" ou "voltagem" são pouco diferenciados e usados como equivalentes. A bateria é um recipiente que armazena a 'substância' que se move através do circuito, e a "eletricidade" é consumida para produzir luz nas lâmpadas. A idéia de que existe algo movimentando-se pelo circuito é usada em maior ou menor grau por praticamente todos os sujeitos.

\section{b) Eletricidade como Correntes Opostas}

O modelo envolve a noção de dois tipos diferentes de eletricidade e a de pilhas e lâmpadas como componentes bipolares. Cada corrente sai por um terminal da pilha e percorre o circuito. Elas se encontram na lâmpada, produzindo luz e desaparecem como resultado desse processo, o que explica que existe uma única corrente em cada 
fio. Corrente e energia não são conceitos diferenciados e usados indistintamente. Implicitamente, o modelo supõe que a corrente é formada de outras partes menores, por exemplo, de partículas carregadas.

\section{c) Eletricidade como Cargas em Movimento}

Esse modelo é o principal produto do ensino de eletricidade em nível secundário. É um modelo microscópico, em que elétrons, ou prótons em alguns casos, movem-se de um terminal da pilha para o outro através de um circuito. Tal modelo envolve o uso de novas entidades e de analogias mecânicas e antropomórficas para explicar as transformações de energia e a natureza da resistência elétrica. As pessoas que utilizam esse modelo descrevem o funcionamento de um circuito usando uma seqüência temporal de eventos. Isso é similar ao raciocínio seqüencial (Closset, 1983; Rozier e Viennot, 1991) e ao modelo de dispositivos (de Kleer e Brown, 1983), também encontrado em outras áreas do ensino de Física (Driver et ai, 1994).

\section{d) Modelo Científico}

O funcionamento do circuito é normalmente descrito em termos de um vocabulário mais funcional, envolvendo transformações de energia, voltagens e sinais. Entretanto, os indivíduos que usam tal modelo podem dar explicações mais detalhadas quando perguntados sobre ele. Corrente é formada por cargas em movimento sob uma diferença de potencial que cria um campo elétrico no interior do circuito. Como no modelo anterior, ela só pode circular num circuito fechado e é conservada. Quando uma mudança é introduzida num ponto do circuito, por exemplo, abrindo ou fechando uma chave ou acrescentando uma lâmpada, uma 'perturbação' elétrica propaga-se pelo circuito, estabelecendo uma nova situação estacionária.

\section{2 - Modelos de Magnetismo}

Dois aspectos são considerados importantes para a identificação dos modelos de magnetismo: o que é que produz magnetismo num imã e o como se dá a interação magnética entre imãs e outros objetos.

\section{a) Magnetismo como atração}

Esse modelo consiste, essencialmente, no conhecimento prático ou no fenomenológico de que imãs atraem objetos próximos e que isso é uma propriedade intrínseca deles. As pessoas que usam tal modelo não mencionam entidades ou mecanismos para explicar os fenômenos magnéticos. Elas apelam para atributos internos dos imãs ou dos objetos que são atraídos, por exemplo, a "energia" ou a "força" do imã. Tais sujeitos não distinguem atração de repulsão nem aparentam reconhecer a existência de pólos nos imãs.

\section{b) Magnetismo como nuvem (ou área de influência)}

Tal modelo acrescenta que a ação dos imãs se manifesta dentro de uma região limitada de influência. Objetos dentro dessa região são atraídos, enquanto que objetos que não são atraídos estão fora do alcance do imã, isto é, do "campo magnético". Os usuários desse modelo referem-se ao padrão de limalha de ferro espalhada em torno de um imã como o campo magnético dele. O magnetismo é causado pela organização interna dos átomos e das moléculas segundo arranjos especiais um objeto está magnetizado quando seus átomos estão ordenados, embora o significado de ordenado possa ser diferente para diferentes usuários. Em geral, os sujeitos apenas contrastam os estados de ordem e desordem para os átomos, estados esses que correspondem, respectivamente, à existência e à não-existência de magnetismo no material. O campo magnético é descrito como uma nuvem ou como uma atmosfera que envolve os 
corpos magnetizados. Embora as pessoas falem em pólos magnéticos, eles não entram nas suas explicações.

\section{c) Magnetismo como Eletricidade}

Esse modelo inclui mecanismos para explicar a atração magnética, baseada em cargas elétricas. O magnetismo é devido à atração entre cargas opostas. Os pólos são regiões que contêm cargas opostas - positiva, ou prótons, em um deles e negativa, ou elétrons, no outro. A fonte desse modelo é a noção de um corpo eletrizado, e o modelo tem o propósito de explicar a existência de pólos distintos nos objetos magnetizados e a indução de magnetismo em certos objetos. O modelo leva à predição de que todos os condutores elétricos são atraídos por um imã, embora alguns dos sujeitos saibam, 'por experiência própria', que certos metais não são atraídos.

\section{d) Magnetismo como Polarização elétrica}

Esse modelo é um refinamento do modelo anterior. Os fenômenos magnéticos são explicados, supondo-se que ocorre uma separação de cargas elétricas nos objetos envolvidos, o que dá origem aos pólos. Nos imãs, esse fenômeno é permanente, enquanto que em objetos metálicos a "imantação" é temporária. Em geral, supõe-se que o campo magnético atua sobre os átomos e as moléculas, girando-os de modo que se alinhem com o campo. Com isso, formam-se camadas alternadas de cargas positiva e negativa. Para explicar o comportamento de diferentes objetos próximos a um imã, o modelo supõe que esse processo de polarização seja difícil de ser feito em determinados materiais, embora campos magnéticos intensos possam atrair metais como cobre e alumínio. Há uma grande similaridade com a explicação da polarização elétrica de dielétricos: no caso de dielétricos, admite-se que materiais não condutores podem tornar-se condutores na presença de um campo externo suficientemente intenso.

\section{e) Científico}

A interação direta entre pólos é substituída pela ação do campo. O magnetismo existe em nível microscópico como resultado do movimento de cargas elétricas ou devido à existência de imãs elementares. Muitas vezes, o modelo não é completamente estruturado, porque não é claro como ocorre interação entre o campo e os átomos de um material. A idéia de microcorrentes que circulam dentro dos imãs e materiais ferromagnéticos é a causa mais freqüentemente citada para a existência de magnetismo.

\section{4 - Modelos de Eletromagnetismo}

Esses modelos dizem respeito ao funcionamento de eletroímãs e aos processos de criação de magnetismo neles.

\section{a) Fusão entre Eletricidade e Magnetismo}

Esse modelo consiste de um conjunto de noções que não distingue fenômenos elétricos de magnéticos. O núcleo do eletroímã é normalmente tomado como sendo um imã, e a existência desse imã permanente é necessária para que o eletroímã funcione. As pessoas, nesse grupo, enfrentam muitas dificuldades para fazer previsões e explicar o comportamento do eletroímã. 


\section{b) Eletricidade no Núcleo}

O eletroímã também só funciona se tem um núcleo que se magnetiza quando uma corrente elétrica circula através dele, ou quando a polaridade da pilha é transferida para o núcleo, encostando-o nos terminais da pilha. O primeiro processo de produção de magnetismo envolve uma corrente que circula pelo núcleo. Portanto, o núcleo deve ser condutor elétrico e deve haver contato elétrico entre o fio do enrolamento e o núcleo. Dessa forma, um eletroímã feito com fio encapado não deve funcionar. Para explicar a magnetização residual do núcleo, as pessoas supõem que um resto de corrente ainda circula depois que a pilha é desligada do circuito, como a água que fica numa mangueira quando se fecha a torneira. $\mathrm{O}$ segundo processo de magnetização do núcleo parece derivar de um modelo de magnetismo como eletricidade ou como polarização elétrica.

\section{C) Modelo Científico ou Eletrodinâmico}

O modelo é caracterizado pela idéia de que uma corrente elétrica sempre cria um campo magnético: o eletroímã é visto como um imã temporário, que pode ser controlado através da corrente, mesmo quando não há um núcleo sólido ou quando ele não conduz eletricidade. As pessoas que usam tal modelo explicam, facilmente, o funcionamento e o comportamento do eletroímã.

\section{Como os Modelos Evoluem}

Uma outra análise dos resultados foi desenvolvida, procurando por tendências comuns aos modelos dos três domínios estudados. Procurou-se examinar, detalhamente, os modelos usados pêlos sujeitos. O quadro 1 apresenta os modelos identificados, organizados por ordem de complexidade, do ponto de vista do pesquisador. Os modelos, no início de cada seqüência, são caracterizados pelo uso não diferenciado das noções usadas para falar sobre os eventos no domínio e pelo fato de que são baseados em propriedades salientes dimento para outro, nos dois casos: (i) um princípio de natureza geral que determina que, na passagem para um plano superior de entendimento, o conhecimento anterior é integrado ao novo; (ii) um processo, também geral, que conduz um entendimento baseado nos atributos dos objetos envolvidos a um entendimento baseado nas relações entre os objetos e as transformações possíveis e, finalmente, a uma compreensão relacionada à construção de estruturas (Piaget e Garcia, 1989). O segundo dos mecanismos, que define uma seqüência de progressão no estado de conhecimento do sujeito, chamado de tríade INTRA, INTER e TRANS, constituiu o ponto de partida para essa análise, embora resultando em quatro níveis.

\section{Nível 1}

Esse nível é caracterizado pelo uso não diferenciado de termos como "energia", "eletricidade" e "força", e "eletricidade" e "magnetismo". Eletricidade e magnetismo são tratados como entidades reais, e os sujeitos, nesse grupo, não mencionam mecanismos internos na explicação das situações observadas. As representações dos objetos envolvidos nas atividades, tais como pilhas, lâmpadas e imãs, são muito simplificados e destituídos de estruturas internas. A pilha, por exemplo, é um reservatório de energia que dá energia para a lâmpada acender (modelo fonterecipiente). Quem tem uma representação assim não vê a necessidade de se ter um circuito fechado para acender a lâmpada e não vê razões para distinguir energia e corrente elétrica, por exemplo (Shipstone, 1985). 
Se considerarmos que os modelos mentais são causais, poderíamos ser tentados a pensar que a denominação mais adequada para esse grupo é a de "não-modelo", incluindo aí os modelos iniciais em cada seqüência (eletricidade como fluxo, magnetismo como atração, eletromagnetismo como fusão entre eletricidade e magnetismo), porque eles não elucidam os mecanismos que explicam o comportamento dos sistemas tratados. No entanto, isso corresponde a uma compreensão muito limitada do que é uma causa. As explicações que os sujeitos, nesse nível, dão para os eventos observados são baseadas em atributos intrínsecos e salientes dos objetos envolvidos. Apenas estudantes da $1^{\mathrm{a}}$ série do segundo grau e técnicos são encontrados nesse grupo.

A seguir, transcrevo trechos da entrevista do eletricista José como exemplo de como alguém no nível l pensa sobre eletromagnetismo. À época da entrevista, José (Tec-08) trabalhava há cinco anos como eletricista. Ele completou os três primeiros anos da escola primária e desistiu para trabalhar numa fazenda. Mais tarde, ele migrou para Belo Horizonte onde começou a trabalhar na construção civil, como servente de pedreiro. Ele não teve treinamento formal em eletricidade: foi aprendendo com os colegas no trabalho, até passar a aprendiz de eletricista, posto que ocupou durante dois anos.

\section{Eletricidade}

A corrente elétrica para ele é como água que escorre para movimentar algum dispositivo. O uso que ele faz do vocabulário técnico reflete o fato de ele nunca ter estudado eletricidade. Ele não diferencia corrente elétrica de energia ou eletricidade.

S: Corrente é aquilo que traz energia, é o que faz as coisas funcionarem ... É o que passa nos fios... É como se fosse uma corrente de força ou uma água correndo que movimenta alguma coisa ...É uma corrente de energia que movimenta alguma máquina ... existe voltagem, corrente ... amperagem e outras coisas ...É tudo a mesma coisa quando relacionado com eletricidade.

José não tem dificuldade de montar o circuito para acender a lâmpada e baseia sua explicação sobre o funcionamento do mesmo em procedimentos de montagem de circuitos elétricos na prática. Ele sabe como fazê-lo e reconhece os componentes elétricos como dispositivos bipolares. De acordo com essa regra, os componentes elétricos realizam certas funções quando corretamente ligados num circuito fechado. A pilha, por exemplo, é um reservatório de energia e contém dois tipos de 'energia': cada um saindo por um dos terminais. Os fios, por outro lado, são condutores de energia. O processo de condução acontece quando o positivo é 'fechado' com o negativo, estabelecendo um circuito fechado. Esse modelo é muito semelhante à 'gestalf da causação introduzida por Andersson (1986), em que a corrente elétrica é vista como um instrumento que sai da fonte de causação para atuar sobre um objeto.

E: O que faz a lâmpada brilhar?

S: Ela tem energia, né? A corrente de energia ... Essa pilha foi carregada com uma certa quantidade de energia. Eu ligo o positivo e o negativo dela no positivo e no negativo da lâmpada, que tem uma resistência, isso acende a lâmpada. (Você pode trocar as ligações?) Posso sim. Não tem problema nenhum. E: O que está acontecendo na pilha enquanto a lâmpada está acesa? S: Tem um consumo. Ela está descarregando a energia que ela guardou (Como é que se coloca energia na pilha?) Pelo que eu sei, é por meio de um curto. ( O que é que existe dentro dela?) Um pino de carvão e uma espécie de pó ... Eu já abri uma pilha só para ver o que tinha dentro. E: O que está acontecendo nos fios? 
S: Eles passam a energia, porque eles são condutores (Como é que essa energia passa?) Fechando o positivo com o negativo, exatamente como eu acabei de fazer aqui com a lâmpada ... Então ela forma uma resistência.

A pilha é um reservatório passivo de 'energia'. Ao realizar o experimento de substituir uma pilha média por uma pequena, José verifica que a lâmpada brilha mais com a pilha menor, mas trata o desacordo com sua previsão como não problemático. $\mathrm{O}$ resultado apenas indica, para ele, qual das pilhas está mais 'usada' e não necessita de mais explicações. No modelo dele, os termos corrente, eletricidade e energia não são diferenciados e referem-se àquilo que flui pelo circuito. Não há qualquer menção a transformações de energia no circuito, ou de causas para o fluxo de corrente. $\mathrm{O}$ fato de ter um circuito completo é suficiente para explicar o funcionamento ou não do mesmo. Isso define o modelo de "eletricidade como fluxo".

\section{Magnetismo}

José afirma não saber nada sobre magnetismo e cita o fato de não trabalhar com magnetismo diretamente como justificativa. Ele reconhece um imã depois que o usa para apanhar um clipe de papel. Ele dá uma boa descrição da estrutura de um microfone e atribui a produção de som ao fato de colocá-lo num campo magnético. E; Você sabe que equipamentos usam imãs? S: Guitarra eiétrica, aparelho de rádio, alto-falante e microfone... O microfone tem um imanzinho dentro dele, parecido com um botão. Ele tem um furo com um pino de ferrite e fio enrolado em volta dela ... Tudo isso forma o fone. (Como é que ele produz som?)

Bom, se eu colocar ele no campo magnético criado por este imã, ele produz som.

E: Por que é que o imã se comporta desse jeito?

S: Ele tem um campo de energia... (Existe alguma coisa dentro de um imã?) Não tem nada (O que aconteceria se você partisse um imã em dois?) Ia dar dois imãs, como estes (Por que você acha isso?) Eu não sei porquê ... Eu sei que um imã atrai ferro.

José explicou antes que sabe como fazer um imã, pois ele costuma magnetizar suas chaves de fenda para segurar os parafusos e facilitar seu trabalho. Ele usa a chave de fenda como núcleo de um eletroímã e explica que é o choque elétrico que magnetiza a chave. Na visão dele, um ímã colocado sob o tampo de uma mesa consegue agir sobre um clipe sobre ela, porque um 'campo' vai do imã para o clipe através da madeira.

S: Eu sei [fazer um imã]. Eu faço isso com choque elétrico. (Como é que é isso?) Eu uso isso para colocar magnetismo nas chaves de fenda. Eu enrolo um fio em volta de uma chave e ligo as pontas na tomada. Instantaneamente, eu ponho um imã nela por muitos dias ... isso funciona melhor do que colocar um imã encostado na chave. E: Quais desses materiais você acha que o imã vai atrair? S: Esse clipe e essa peça de latão. Ele não atrai alumínio nem cobre. (Experimente)... Ele só atraiu o clipe .(Por que você pensou que ele iria atrair esses materiais?) Eu não tinha experimentado com o cobre ainda.

No seu modelo, há a necessidade de algo que estabeleça uma conexão entre a fonte das ações e o objeto sobre o qual ela atua. Ao explicar por que um imã consegue atrair alguns objetos, ele não menciona quaisquer entidades ou mecanismos internos. Esse comportamento é intrínseco ao imã. Isso caracteriza o seu modelo de magnetismo como atração.

\section{Eletromagnetismo}


José não reconhece o eletroímã feito de fio esmaltado e pensa, inicialmente, que se trata de uma 'resistência'. A razão para isso é, provavelmente, o uso comum de resístores de fio em chuveiros elétricos. Depois que ele aproxima uma bússola do imã, ele o reconhece como tal.

$\mathrm{S} /$ /sso é uma resistência (Para que isso é usado?) Ela esquenta.

E usada também em etetrônica... [Aproxima a bússola do eleíroímã] Isso é aquilo que eu disse que fazia ... O imã com a chave de fenda e energia; então ele vira um imã. (Isso é um imã?) É sim... Em sua visão, magnetismo é criado no núcleo do eletroímã. Dessa forma, ele prediz que o magnetismo acabará assim que o núcleo for retirado. Ele fica desconcertado com a observação de que o fio enrolado ligado à pilha continua a produzir efeitos sobre a bússola. E: O que você acha que acontecerá se eu tirar esse pino? S: O magnetismo vai acabar .... Por que o magnetismo é criado nesse pino de ferro. [Ele é retirado e a bússola é colocada próxima ao enrolamento. A agulha move-se quando o fio enrolado é aproximado ou afastado] Ele ainda está descarregando.... Ainda tem um pequeno efeo.... Interessante, não é? $O$ pino é colocado em seu lugar original e José usa o eletroímã para levantar um clipe. Ele prediz que o clipe continuará preso se a pilha for desligada, porque o núcleo fica magnetizado. A sua experiência em imantar as chaves de fenda fornece o modelo para que o núcleo de ferro fique magnetizado. No entanto, ele ainda pensa nos efeitos do fio enrolado como resístor.

S: Eu acho que essa bobina reduz a corrente, independentemente do campo magnético que ela cria. Ela diminui a corrente... Quanto mais voltas ela tiver, mais ela diminui a corrente (Como você poderia tornar esse imã mais forte?) Aumentando a corrente de energia...

José acredita que o segundo eletroímã, feito de fio encapado com plástico, é ainda mais potente. A razão é que a isolação elétrica aqui é maior. Isso parece surpreendente, mas, como eletricista, ele sabe que condutores elétricos devem ser isolados para não produzirem curto-circuito. Além disso, ele, provavelmente, usou fios desse tipo para imantar suas chaves de fenda. Ao explicar por que o eletroímã continua a segurar um clipe, depois que a pilha é desligada, José aponta que o núcleo de ferro já está magnetizado:

ele tem que estar magnetizado para atrair o clipe.

S: Esse é mais forte porque a isolação aqui é maior: esse fio está encapado com plástico.

E: Use-o para pegar e levantar o clipe. .. Mantenha-o no alto. O que você espera que aconteça com o clipe se desligar a pilha?

$S$ : O clipe fica preso, do mesmo jeito que antes. O resutado está de acordo com a previsão] Isso é porque esse ferro já está com magnetismo. Ele tem que estar magnetizado para fazer essa experiência.

$\mathrm{O}$ modelo mental de magnetismo de José não distingue entre os fenômenos magnéticos e os fenômenos elétricos. Embora aponte que é possível criar magnetismo com 'choque elétrico', ele não parece compreender como isso pode ocorrer. Suas respostas derivam de um saber prático e não refletido sobre eletricidade e magnetismo,

\section{Nível II}

Indivíduos, nesse grupo, explicam as situações em termos de entidades e estruturas simples como, por exemplo, carga elétrica, pólos de um imã ou encontro de correntes que viajam em sentidos opostos, produzindo luz. Entretanto, não existe a idéia clara de interação entre objetos distintos. Com isso quero dizer que a interação entre os objetos envolvidos em cada situação não parece ser necessária para os sujeitos do estudo, mas circunstancial. Por exemplo, um imã atrai objetos de ferro, porque eles estão dentro do campo magnético, ou porque o imã tem pólos opostos, o que lhe dá a 
capacidade de atrair. Os sujeitos, nesse grupo, usam algumas idéias gerais, como a idéia de que os opostos se atraem, como se fossem causais e tendem a descrever as situações observadas em termos de sequiência temporal de eventos discretos.

$\mathrm{O}$ caso de Guilherme ilustra bem tais características. Quando a entrevista foi realizada, ele estava no primeiro ano do segundo grau de uma escola católica reconhecida como de boa qualidade e bem-sucedida na preparação de seus alunos para o vestibular. Noções de eletricidade são ensinadas nas aulas de ciências, mas elas não tratam de circuitos elétricos.

\section{Eletricidade}

Guilherme recebe uma lâmpada, uma pilha média e pedaços de fio para fazer a lâmpada acender. Ele tenta, repetidamente, ligar os dois fios à base da lâmpada e explica que recolocar os fios positivo e negativo juntos resulta numa corrente elétrica. Durante a conversa, ele acidentalmente separa os fios e faz os contatos corretamente. A lâmpada acende durante um curto intervalo de tempo. No entanto, Guilherme não percebe o que ele fez de diferente para acender a lâmpada. Ele não diferencia corrente de potencial ou corrente de energia.

$E$; Você acha que os dois fios devem ir juntos aí?

S: Sim .... Porque juntando um pólo positivo e outro negativo forma uma corrente elétrica... (E então?) Daí a lâmpada acende. (O que acontece com essa corrente?) As cargas negativas encontram com as positivas. Eu não tenho certeza sobre isso, mas acontece alguma coisa... Um fenômeno que gera eletricidade. (Você acha que os dois fios são diferentes?) Exatamente ... Este fio azul está ligado no pólo positivo da pilha e o fio vermelho está no poio negativo. Então, quando eles se juntam na lâmpada, aparece uma corrente elétrica e a lâmpada acende.

E: O que é corrente elétrica para você?

S: São partículas com carga elétrica em movimento pelo fio.. Eu não sei se são prótons ou elétrons. O que eu sei é que o que passa num fio é o contrário do que passa no outro. Então, colocando juntas essas duas energias, forma uma corrente.

E: O que faz a lâmpada acender?

S: É o choque das partículas positivas com as negativas (E depois do choque, o que acontece?) Elas se chocam e se cancelam ... elas provocam essa luz e se cancelam.

Guilherme raciocina que duas espécies diferentes de eletricidade viajam pêlos fios e se chocam na lâmpada, produzindo luz. Como resultado elas se anulam, e nada retorna para a pilha. O que quer que seja que passe pêlos fios se aniquila na lâmpada e é transformado em luz. Guilherme adota duas visões de corrente: uma como partículas eletricamente carregadas que se movem através de cada um dos fios e outra em que ele afirma que a corrente é formada a partir do encontro dos dois tipos de eletricidade. Depois ele admite que as duas eletricidade só se encontram no filamento da lâmpada. $O$ mecanismo de condução se dá por saltos de partículas entre átomos contíguos. Nesse meio tempo, ele recebeu um soquete para a lâmpada e só então consegue acendê-la.

$S$; Assim é mais fácil (Isso está ligado da forma que você pensava?) Não... Eu acho que os dois fios não se encostam aqui embaixo. Eles só se encontram naquela molinha [o filamento da lâmpada] ...eu acho que o que está num fio só se junta com o que está no outro naquela peça.

E: O que está acontecendo na pilha?

S: Ela tem dois pólos: positivo e negativo. O que produz luz na lâmpada é o encontro das partes positiva e negativa ( $\mathrm{E}$ nos fios, o que acontece?) As partículas elétricas estão em movimento ... o fio é condutor ... ele tem muitos átomos. Um elétron chega 
num átomo e ele manda um elétron para um outro átomo, e assim por diante. (Como é isso, um empurrando o outro?) É, pode ser... O átomo é neutro. Se chega mais um elétron, ele deixa de ser neutro. Então, o átomo tende a atingir a estabilidade ou neutralidade e aí ele expele um elétron.

Guilherme pensa que a pilha é um reservatório de partículas elétricas. Isso significa que ele não menciona nenhum processo interno ocorrendo nela. No seu modelo de eletricidade, há duas correntes, de partículas positivas e negativas, que se movem a partir de cada um dos pólos da pilha e se chocam no filamento, produzindo luz. $O$ modelo não distingue corrente elétrica de energia e tem a não-conservação da corrente como conseqüência.

\section{Magnetismo}

Para Guilherme, um campo magnético é uma região em torno de uma fonte de magnetismo. Tal objeto tem a propriedade de atrair tudo que penetra no seu campo, tal como um planeta que atrai os objetos que se movem nas suas vizinhanças.

S: Magnetismo? É atração ... isto é, eu penso num imã que atrai objetos ... como o ferro (O que vem à sua mente quando você pensa em campo magnético?) Campo magnético é um espaço, um certo espaço e tudo que penetra nesse espaço é atraído.... por alguma força ou matéria que cria esse campo magnético. (Como é esse campo magnético?) É como um planeta. Um planeta tem um campo magnético e consegue atrair os objetos que estão dentro desse campo. Um meteoro que passa por perto é atraído.

Ao explicar o comportamento do imã em atrair ferro, Guilherme refere-se a existência de uma parte positiva e de outra negativa. Isso, entretanto, não parece ligado a um modelo de magnetismo baseado em eletricidade.

S: É um imã porque ele atrai o clipe (Para que ele é usado?) Para pegar objetos metálicos (O que mais?) Bom, ele tem muitas utilidades. Por exemplo, uma usina de reciclagem de lixo usa imã para separar ferro do resto do lixo, porque ele tem a propriedade de atrair alguns objetos.

E: Por que é que o imã tem esse comportamento?

S: Ele tem um lado positivo e outro negativo ... Isso dá a ele a propriedade de atrair algumas substâncias.

Isso parece ser apenas uma maneira de se referir aos poios magnéticos. Ele está mais comprometido com a idéia de magnetismo como alguma 'força' que age em uma região limitada em volta do imã. Um objeto que se encontra dentro dessa região é necessariamente atraído. Outras forças não são levadas em consideração, de forma que atração existe apenas se o objeto se move.

$\mathrm{E}$; Por que é que o imã atrai o clipe mesmo de longe? S: Se o clipe está perto do imã, ele está dentro do campo magnético e isso é suficiente para provocar a atração. Eles não precisam de estar em contato... a única condição é que ele esteja dentro do campo magnético.(Vamos supor que você tivesse dois imãs, como estes. Como você poderia decidir qual deles é o mais forte?) O maior é o mais forte ( Por que você acha isso?) Porque o campo magnético dele é maior.

$O$ modelo "magnetismo como área de influência" parece se ajustar melhor às idéias de Guilherme sobre o assunto. Nesse modelo, não há mecanismos propostos para explicar a atração. O magnetismo é uma propriedade intrínseca de imãs e age numa área limitada do espaço em volta dele. Tal idéia lembra as concepções de gravidade terrestre comum entre estudantes mais novos, segundo as quais a atração gravitacional da Terra sobre outros objetos só existe na região onde há atmosfera. 


\section{Eletromagnetismo}

Guilherme reconhece que a função do eletroímã é criar um campo magnético. Tal campo é criado pela corrente no circuito. Essa corrente, de acordo com ele, passa através do núcleo do eletroímã e ele se imanta. Guilherme também usa os termos 'eletricidade' e 'energia' em suas explicações.

$\mathrm{E} ; \mathrm{O}$ que é isso?

S: É um metal com um fio enrolado e ligado a uma pilha (Para que isso é usado?) Isso é um imã ... a energia da pilha transforma o metal em um imã e ele atrai objetos. (Ele se transforma num imã?)

Ele não tem magnetismo agora. O magnetismo vem da energia ... a eletricidade que passa por ele ... a corrente elétrica que passa pelo ferro forma um campo magnético. (Para que é que isso serve?) Talvez para magnetizar ferro (Você já viu isso antes?) Não Quer dizer, eu vi uma experiência em que um pedaço de ferro era transformado em imã.

Ele prediz que uma bússola colocada perto do eletroímã ligado irá apontar para o núcleo do mesmo. Ele se refere a um experimento similar, que envolvia a bússola e um imã em barra, feita em outra parte da entrevista. Diferentemente de então, Guilherme agora explica o comportamento do eletroímã em termos da ação de seus pólos. Ele também prevê que, ao retirar o núcleo, o efeito sobre a bússola desaparece, porque a corrente cria magnetismo no núcleo. Ele muda de idéia, com a observação de que a bússola continua sendo afetada, e propõe que o núcleo de ferro aumenta a força magnética.

S: A agulha da bússola vai apontar para o ferro (Por que é assim?) Porque o ferro transformou-se num imã. É igual à experiência em que a bússola apontava para o imã. E: Experimente/ pausa/ O resultado é o que você esperava? S: É. O ferro agora é igual a um imã. Ele tem um norte e um sul... Todo imã tem dois lados: norte e sul.

E: Ele continua a afetar a bússola se eu tirar o núcleo de ferro? S: Não, assim ele não funciona (Por quê?) Ele precisa de uma substância, de um corpo dentro dele ... Isso não consegue atrair a bússola (Experimente) Hum, ele está atraindo ... É porque a corrente elétrica cria um campo magnético... mas eu achava que ele precisava de um pedaço de ferro. (Para que é que serve esse ferro?) Bom... como ele continua atraindo [sem o núcleo] ele deve ser para aumentar a força magnética (Como assim?) Eu não sei... eu só sei que o ferro aumenta a força.

Guilherme prevê que, desligando o circuito, fará com que o magnetismo desapareça completamente. Sua concepção é a de que a anulação da corrente (causa) leva ao desaparecimento do campo magnético (efeito). Face à evidência contrária, ele passa a admitir que o núcleo se transformou num imã permanente. Isso é diferente de seu raciocínio inicial em termos de uma causa que produz um efeito, de forma que, retirando-se a causa, se extingue o efeito. Esse tipo de raciocínio tem sido observado entre estudantes de ciências de várias idades (Andersson, 1986; Rozier e Viennot, 1991). Embora funcione bem na maioria da situações escolares, isso não funciona aqui por causa da magnetização residual do núcleo. S; O clipe vai cair (Por que você acha isso?) Porque a corrente etétrica-vai parar e o campo magnético também. [A pilha é desligada e o clipe não cai] É... ele não caiu. Não era isso que eu esperava. (O que você acha que aconteceu?) Eu achei que seria como a lâmpada. Isto é, que só desligando o fio iria fazê-lo cair...que o fenômeno acabaria /pausa/ Então, eu acho que esse ferro agora está imantado.

Ele responde que o segundo eletroímã, feito de fio encapado, deve funcionar como o primeiro, mas que o clipe deve cair se a pilha for desligada. A razão para isso é que, 
pelo fato de o fio estar isolado, não é possível ter a magnetização residual do núcleo, como no eletroímã anterior. Isso indica que Guilherme não sabe que o fio, no primeiro caso, está isolado com esmalte. Por outro lado, sugere que ele ainda pensa que a magnetização permanente do núcleo ocorre quando a corrente elétrica passa através dele.

E: Este funciona como o outro?

S: Funciona... Eu acho que funciona. Mas se ele desligar a pilha, como eu fiz antes, o clipe vai cair. (Por que você acha isso?) Eu acho que este plástico é um isolante e impede a passagem da corrente elétrica (E daí?) Então, ele elimina o campo magnético ... Bom, pode ser que esse fio não esteja completamente isolado.

E: Pegue o clipe com ele... Levante-o e mantenha-o no ar. Sua previsão é a de que se desligarmos a pilha ...

S: Agora ele cai... porque o plástico não deixa a corrente elétrica passar pelo ferro. No outro caso, isso era mais fácil. (Você acha que ela passa pelo ferro?) Eu acho [A bateria é desligada e o clipe cai] Era o que eu esperava ... O plástico não deixa a corrente passar no ferro.

$O$ acordo da previsão de Guilherme com o experimento se deve ao fato de que um outro tipo de material, ferro doce, foi usado como núcleo. No entanto, está claro que, no seu modelo, o magnetismo é produzido pela passagem de eletricidade através do núcleo do eletroímã, transformando-o num imã permanente.

\section{Nível III}

Os sujeitos, neste grupo, já têm um razoável conhecimento dos processos internos e mecanismos que produzem os eventos observados. O foco das explicações dos indivíduos desse grupo são as interações entre os objetos envolvidos. Os mecanismos responsáveis pelo comportamento dos sistemas são explicitamente descritos. Por exemplo, ao explicar a atração de um objeto por um imã em termos de eletricidade, os sujeitos descrevem os mecanismos que permitem o aparecimento de pólos do objeto. Tais descrições são, em geral, microscópicas e envolvem modelos mecanicistas para processos elétricos e magnéticos. Ainda persiste a tendência de se expressar, em termos de seqüências temporais de eventos, como no nível anterior.

O caso de Pedro é apresentado a seguir. À época da entrevista, Pedro fazia o terceiro ano do curso técnico de eletrônica. Por estudar numa escola técnica, ele tinha cursado uma disciplina específica de eletricidade e eletromagnetismo no ano anterior. Pedro foi indicado por seu professor de eletricidade por ser um aluno habilidoso no laboratório, embora não tivesse boas notas nas provas. Durante a entrevista, ele revela que escolheu o curso técnico, porque desde pequeno gosta de consertar coisas e de entender como elas funcionam.

\section{Eletricidade}

Pedro pensa sobre eletricidade como cargas elétricas em movimento sob a ação de uma diferença de potencial. Ele monta o circuito para acender a lâmpada sem dificuldade e reconhece que a pilha tem polaridade e a lâmpada, não.

S: Corrente? . É carga em movimento dentro de um condutor (Como é isso?) É como um rio. Tem as margens que é o fio, e o que passa dentro dele é a corrente elétrica. Tem uma diferença de potencial entre dois pontos e ela faz a carga fluir de um ponto para o outro.

E: O que é que faz a lâmpada acender? 
S: A presença de uma corrente que circula em seu filamento ( A simples passagem de uma corrente a acende?) Não. Ela tem um filamento fino, um pequeno fio enrolado. Quando a corrente passa por ele, ele aquece e emite luz... Ele transforma parte da energia elétrica em calor e luz.

Seu modelo de uma pilha já inclui mecanismos para explicar o 'desgaste' da mesma com o uso e para manter uma diferença de potencial entre os seus terminais. Pedro descreve o funcionamento do circuito com detalhes, fazendo uso de um modelo mecanicista em que cargas elétricas são injetadas no circuito pela pilha e o percorrem retornando ao terminal de potencial mais baixo. A diferença de potencial atua como uma força impulsora que obriga as cargas a se moverem através do circuito. $O$ foco de suas explicações não são cadeias de causas e efeitos, comum entre os estudantes da terceira série de ambas as escolas, mas alguns princípios físicos e os processos que ocorrem no circuito.

E: O que acontece na pilha e nos fios enquanto a lâmpada está acesa?

S: /pausa/Bem, o fio é um simples condutor, sem polaridade, tal como a lâmpada. Se eu inverter as ligações é a mesma coisa. Já a pilha tem polaridade. Um terminal é positivo e o outro é negativo. Há uma queda de tensão entre eles... O que acontece é que a corrente elétrica sai por um pólo, move-se pelo circuito e retorna.

$\mathrm{E}: \mathrm{O}$ que é que produz corrente nos fios?

S: A corrente é produzida por esta pilha. O fio não pode produzi-la. (Como é que pilha faz isso?) Pelo que eu sei, a pilha é feita de dois materiais diferentes: ela tem carvão e um material que produz corrosão nele ... Há uma reação entre estes dois materiais e ela produz hidrogênio, que forma uma camada em volta do eletrodo de carvão; a camada de hidrogênio dificulta a passagem de corrente elétrica... A pilha sofre uma transformação química e estabelece uma diferença de potencial entre estes dois materiais.

E: Como é que esta diferença de potência! provoca a corrente?

S: Os materiais estão separados. Não, eles não estão tão separados. Eles trocam cargas elétricas ... é isso que dá à pilha esta capacidade de jogar corrente no circuito. Mas ela diminui com o tempo por causa da produção de hidrogênio.

\section{Magnetismo}

Pedro compreende magnetismo como atração entre corpos eletrizados. Sua idéia de magnetismo depende muito de sua compreensão de interação elétrica. Ele não menciona repulsão nessa explicação e parece-lhe difícil explicá-la sem a adoção de modificações no modelo. Pedro parece sentir dificuldades com sua explicação ao falar de campo magnético e passa a usar a regra de atração entre cargas contrárias e de repulsão entre cargas iguais, mas ainda cargas elétricas.

$S$; Magnetismo é atração entre dois corpos (Como é isso?) Considere dois corpos, ou apenas dois átomos se você quiser. Tire um elétron de um átomo e passe-o para o outro. O segundo átomo ficará com um excesso de carga negativa e o primeiro terá um excesso de carga positiva. Se eu aproximo um do outro, eles irão se atrair, porque um perdeu elétrons se os quer de volta para alcançara estabilidade elétrica. (Isso é devido ao magnetismo?) É isso aí... isso é o que é chamado de magnetismo: um corpo atrai o outro para ficar eletricamente neutro.

$\mathrm{E}: \mathrm{O}$ que vem à sua mente quando você pensa em campo magnético? 
S: No caso desses corpos que se atraem há alguma coisa entre eles que faz um atrair o outro e ficar eletricamente neutro ...Eu poderia usar uma outra linha de raciocínio ( Qual?) Cargas iguais se repelem e cargas contrárias se atraem. Então, o que acontece é que um lado é positivo e o outro é negativo e, no espaço entre eles, há um meio.

Mais tarde, Pedro explica como um imã consegue atrair um pedaço de ferro. Ele lança mão da idéia de organização dos átomos de ferro: sob a ação de imã, eles alinham-se paralelamente, transformando o pedaço de ferro em um imã temporário. Pedro enfatiza que o campo do imã provoca a formação de camadas de cargas positivas e negativas, em sucessão, dando origem a algo como a polarização em um dielétrico na peça. Ele também explica que não é todo tipo de material que se comporta dessa forma, porque os materiais apresentam uma resistência à formação de tais arranjos de átomo que é diferente de um material para outro. E: Você falou em materiais ferromagnéticos. O que é isso?

S: Existe uma orientação dos átomos deles, eles estão todos praticamente na mesma direção. Eles têm uma organização espacial ... Ela transforma esta barra de ferro em um imã ... O campo do imã alinha camadas sucessivas de cargas: positiva e negativa, depois positiva e negativa de novo, lado a lado ... Com este alinhamento que o campo produz, ele transforma a barra num bloco com uma certa orientação atómica. E; Todos os materiais se comportam desse jeito? S: Não (Por que não?) Devido à própria tendência dos átomos em formar grupos, isso é fácil de se conseguir no ferro, mas em outros materiais há uma certa resistência mecânica que dificulta o acontecimento de tal processo.

Pedro tem um modelo sofisticado de magnetismo e o usa coerentemente a maior parte do tempo. O que distingue o seu modelo de magnetismo é a forma como ele explica a origem do magnetismo em imãs e a magnetização de materiais ferromagnéticos.

\section{Eletromagnetismo}

Pedro reconhece, de imediato, o eletroímã usado na primeira atividade. Ele consegue resolver bem a maior parte das situações. Por exemplo, ele prediz que a agulha da bússola irá apontar para o núcleo de ferro quando ambos estiverem próximos. Pedro usa seu modelo de magnetismo como polarização elétrica para explicar como o eletroímã consegue agir sobre objetos a distância. Isso se deve à ação do campo magnético que reorganiza os constituintes do objeto atraído. Dessa forma, o objeto adquire uma polaridade contrária à do eletroímã e é atraído. Novamente, isso parece ser visto como um processo e não como uma seqüência de episódios que envolvem causa e efeito.

S: isso é um eletroímã ... Descobriu-se que, quando uma corrente passa num fio, ela produz um campo em volta dela. Se eu enrolo o fio em volta de um bastão de ferro, ele reforça as ligações entre os átomos (Como assim?) Por causa do próprio campo magnético que o fio cria.

E: Use este eletroímã para levantar o clipe ... Mantenha-o no alto. Por que o eletroímã consegue atrair alguns objetos mesmo sem tocá-los?

S: Porque ele se comporta como um imã. (Como é que esta propriedade aparece nele?) Há um campo magnético aqui em volta dele, isso já foi provado. Este campo interage com o clipe e o reorganiza. Assim, o clipe ganha uma polaridade, como um imã, mas com pólos opostos.

Sua predição para o comportamento do clipe ao desligar o eletroímã falha, porque ele não considerou os efeitos de magnetismo residual no núcleo. Mas ele se dá conta disso, após a observação dos resultados do experimento. 
$\mathrm{E}$; O que você espera que aconteça se você desligar o eletroímã?

S: Uma vez que não tem mais corrente no fio, o campo magnético vai desaparecer. Assim, o ferro vai perder seu magnetismo e o clipe vai cair.

E: Experimente [A pilha é desligada do circuito, mas o clipe não cai] O resultado é o que você esperava?

S: Não (Como você pode explicar isso?) [O clipe cai] Ah, aí está ... mas eu poderia supor um campo residual (Teste com a bússola) Este núcleo ficou magnetizado.

Pedro prevê que a bobina apenas produz efeito sobre a bússola, quando o núcleo do eletroímã é retirado, embora esse efeito seja mais fraco que antes. Seu pensamento é de que a bobina cria um campo magnético, independentemente de existir ou não um núcleo, mas tem a função de reforçar tal campo.

E: E o que acontece se eu tirar esta peça daqui?

S: O eletroímã não vai mais afetar a bússola [Ele está se referindo ao circuito desligado ...A pilha é ligada ao enrolamento sem o núcleo] (Vamos ver) Não. Se você ligar a pilha, ele vai atrair a bússola (Por que você acha isso?) Tem um campo magnético criado pela corrente. Então, a bobina se comporta como um imã (Mesmo sem um núcleo?) O campo é mais fraco (Por quê?) Quando a corrente flui pelo fio, ela cria um campo. Se existe um núcleo, ele reforça esse campo.

No final, Pedro afirma que o segundo eletroímã funciona da mesma forma que o primeiro e aponta que o fato de o fio estar encapado não isola o campo magnético. $\mathrm{O}$ campo magnético passa através da camada isolante de plástico e, assim, não há diferenças em termos de funcionamento nos dois casos.

S; À primeira vista, parece um etetroímã (Ele funciona da mesma forma que o outro?) Eu posso testá-lo (O que você espera?) O núcleo parece ser de ferro ... ele funciona como o outro. Não importa o fato do fio ser isolado (Por que não?) $O$ campo passa através dessa capa. O plástico não é um isolante para o campo magnético... [Repetido o experimento com o clipe] Vai ser o mesmo de antes. $O$ campo vai passar através desse plástico. Não há diferença entre os dois e tetro imãs. $O$ modelo de Pedro para explicar o funcionamento do eletroímã é um modelo Eletrodinâmico que associa um campo magnético com a corrente em qualquer circuito.

\section{Nível IV}

Os sujeitos, nesse nível, podem manter múltiplas visões dos fenômenos, os quais podem ser explicados em termos de modelos mecanicistas ou em termos mais abstratos, usando-se o conceito de campo. Ao explicar as situações, tais sujeitos se referem a entidades e noções que não aparecem nos grupos anteriores - momento magnético orbital, spin, dipolos magnéticos elementares -e substituem a interação entre objetos por interações que envolvem os campos elétrico e magnético.

Nelson (Pro-09) é um professor secundário de Física com muitos anos de experiência no ensino. Quando foi entrevistado, ele estava fazendo uma especialização em ensino de Física. Nesse curso, alguns dos resultados da pesquisa em ensino de ciências foram discutidos, ao lado de cursos específicos que enfatizavam o conteúdo e a evolução dos conceitos de Física.

\section{Eletricidade}

Nelson completa todas as tarefas propostas durante a entrevista sem qualquer dificuldade. Ele usa um modelo qualitativo e microscópico para explicar o funcionamento do circuito com a lâmpada em termos de transformações de energia 
elétrica em luz e calor. Nesse modelo, a pilha estabelece uma diferença de potencial através dos elementos do circuito, que cria um campo elétrico. Tal campo age sobre os elétrons livres para acelerá-los através da rede cristalina. Em vista das sucessivas colisões, os elétrons transferem a energia cinética adquirida para a rede, e o processo de aceleração inicia-se novamente, até que outra colisão ocorra.

$\mathrm{S}$; Porque os elétrons passando pelo filamento da lâmpada colidem com os átomos da rede. Eles são acelerados pelo campo elétrico e, com estas colisões freqüentes, eles perdem energia cinética que é transformada em calor. O filamento aquecido brilha, emitindo luz.

E: O que acontece nos fios e na pilha enquanto a lâmpada está acesa?

S: Uma reação química. Eu não consigo lembrar exatamente que materiais estão envolvidos ( $E$ nos fios?) Sendo metálicos, eles têm elétrons livres. Estes estão submetidos à diferença de potencial da pilha que estabelece um campo elétrico. Esta diferença de potencial é mantida pelo processo químico que ocorre na pilha. Então, o campo elétrico faz estes elétrons se moverem do terminal negativo da pilha para o positivo.

$\mathrm{E}:$ O que é que cria este campo?

S: É a diferença de potencial. É como se a pilha tivesse cargas positivas acumuladas em um pólo e cargas negativas no outro pólo. Eu acho que tudo isso é uma questão de interpretação ... É uma coisa que funciona. (E o que faz este campo ...) Ele age sobre os elétrons produzindo o movimento de cargas, que é a corrente elétrica. (Você disse que os elétrons estão sendo acelerados, certo?) Sim, eu disse. Mas a velocidade de um dado elétron cresceria apenas se não houvesse a rede cristalina. Os elétrons têm de passar através dela e colidem freqüentemente e perdem a energia cinética que eles ganharam do campo ... é uma série de colisões e movimento.

Esse modelo é, essencialmente, o modelo de Drude-Lorentz para a condução elétrica em metais e usualmente ensinado no ciclo básico dos cursos de Física. É um modelo mais acurado que aquele de uma multidão de objetos forçados a atravessar uma passagem estreita ou um caminho cheio de obstáculos, adotado por muitos estudantes da terceira série do segundo grau. Mais tarde, Nelson trata de uma situação em que uma lâmpada incandescente é controlada por meio de um interruptor. Ele explica por que a lâmpada acende imediatamente quando o interruptor é ligado.

S: Porque o campo elétrico viaja com a velocidade da luz ...Quando você liga a chave, cria-se um campo elétrico que se propaga por todo o circuito. Os elétrons livres em cada ponto começam a mover-se todos de uma vez, produzindo uma corrente elétrica.

Sua resposta indica que ele pensa sobre o circuito como um todo cujas partes interagem e sobre quais alterações em um ponto do circuito são comunicadas a todo o sistema com a velocidade da luz.

\section{Magnetismo}

Nelson associa, de imediato, magnetismo com cargas elétricas em um modelo Eletrodinâmico que associa um campo magnético com a corrente em qualquer circuito.

\section{Nível IV}


Os sujeitos, nesse nível, podem manter múltiplas visões dos fenômenos, os quais podem ser explicados em termos de modelos mecanicistas ou em termos mais abstratos, usando-se o conceito de campo. Ao explicar as situações, tais sujeitos se referem a entidades e noções que não aparecem nos grupos anteriores - momento magnético orbital, spin, dipolos magnéticos elementares -e substituem a interação entre objetos por interações que envolvem os campos elétrico e magnético.

Nelson (Pro-09) é um professor secundário de Física com muitos anos de experiência no ensino. Quando foi entrevistado, ele estava fazendo uma especialização em ensino de Física. Nesse curso, alguns dos resultados da pesquisa em ensino de ciências foram discutidos, ao lado de cursos específicos que enfatizavam o conteúdo e a evolução dos conceitos de Física.

\section{Eletricidade}

Nelson completa todas as tarefas propostas durante a entrevista sem qualquer dificuldade. Ele usa um modelo qualitativo e microscópico para explicar o funcionamento do circuito com a lâmpada em termos de transformações de energia elétrica em luz e calor. Nesse modelo, a pilha estabelece uma diferença de potencial através dos elementos do circuito, que cria um campo elétrico. Tal campo age sobre os elétrons livres para acelerá-los através da rede cristalina. Em vista das sucessivas colisões, os elétrons transferem a energia cinética adquirida para a rede, e o processo de aceleração inicia-se novamente, até que outra colisão ocorra.

$\mathrm{S}$; Porque os elétrons passando pelo filamento da lâmpada colidem com os átomos da rede. Eles são acelerados pelo campo elétrico e, com estas colisões freqüentes, eles perdem energia cinética que é transformada em calor. O filamento aquecido brilha, emitindo luz.

$E$ : $O$ que acontece nos fios e na pilha enquanto a lâmpada está acesa?

cada uma apontando em uma direção. Então, o material não tem comportamento magnético macroscópico. Entretanto, quando eu os coloco num campo magnético, estas espiras são influenciadas pelo campo e se alinham com ele. Elas se alinham todas paralelamente ao campo e isso dá características magnéticas ao objeto. (E se você virar o imã ao contrário?) Ele reorienta as espiras ... Elas estão sob a influência do campo magnético do imã. Se você muda o campo, você muda os efeitos também. (E essa idéia de ação sem contato?) Essa idéia de campo é tão ... Há uma modificação no espaço em volta. Quando você aproxima o objeto do imã, ele está sob a influência do campo.

E: Por que é que tais espiras tendem a se alinhar com o campo? S: Tem uma interpretação de que eles tendem para a posição de equilíbrio em que a sua energia potencial é mínima. Todas as coisas têm tal tendência para a menor energia.

\section{Eletromagnetismo}

Nelson reconhece o eletroímã imediatamente e aponta que ele é usado da mesma forma que um imã permanente. Ao explicar sua ação, Nelson usa a similaridade entre a coleção de espiras e seu modelo de magnetismo, no qual corrente microscópicas funcionam como imãs elementares.

S: /sso é um eletroimã (Para que ele é usado?) Ele pode ser usado para muitas coisas. Ele pode ser simplesmente usado como um eletroímã... Ele é um imã e tem todas as funções de um imã permanente. É usado em depósitos de ferro velho para apanhar ferro. 
E: Por que é que ele funciona como um imã?

S: Isso é uma coleção de espiras. Eu imagino o imã como espiras com uma corrente. Experimentalmente, eu sei que um fio onde há uma corrente cria um campo magnético em torno de si mesmo. Quer dizer, ele cria alguma coisa que pode afetar a agulha da bússola, por exemplo. Isto é o que nós chamamos de campo magnético.

Nelson responde a todas as situações corretamente, exceto que se surpreende com a magnetização residual do núcleo do eletroímã.

S: Se eu desligar a corrente, a bússola volta para a direção do campo terrestre. [Faz o experimento de desligar a pilha e não há mudança na indicação da bússola] (Você esperava isso?) Não. Não

há nenhuma mudança na bússola ... É este ferro?

Parece que este núcleo ficou imantado.

E: O que acontecerá com a bússola se eu tirar o núcleo? S: O eletroímã continua afetando a bússola ( Qual é o papel desse núcleo no eletroímã?) Ele aumenta o campo, porque ele tem muitos pequenos imãs não alinhados. Quando ele é colocado aqui, o campo magnético atua sobre eles e produz uma grande magnetização.

Por fim, Nelson prevê que o segundo eletroímã, feito de fio encapado, funciona da mesma forma que o primeiro, desde que o material do núcleo seja o mesmo. O encapamento não tem efeito algum sobre o eletroímã. Seu modelo é essencialmente aquilo que consideramos corn.0 o 'modelo científico'.

Preferimos agrupar os sujeitos deste estudo em quatro níveis, em lugar de três como sugere o estudo de Piaget e Garcia. As pessoas agrupadas no nível II, embora não centrassem suas explicações e previsões em atributos dos objetos envolvidos, não tinham ainda uma clara noção de interação. $O$ exame das sequiências identificadas de modelos mostra que, à medida que as pessoas adquirem conhecimento sobre a área, elas passam a usar modelos mais elaborados, e essas mudanças são caracterizadas por uma série de aspectos;

- Progressiva diferenciação dos conceitos básicos e adoção de um vocabulário mais rico.

- Mudança de modelos fenomenológicos e qualitativos para modelos passíveis de representação matemática mais abstraía. Modelos mais sofisticados não se referem aos fenômenos como eles são percebidos, mas a construções e entidades mais distantes da experiência humana. Envolvidos e explicam os fenômenos em termos de interações entre eles. Finalmente, eles passam a considerar relações de ordem mais alta.

A tabela 1 mostra a distribuição dos sujeitos do estudo por tais níveis. Uma categoria Misto foi incluída aqui. Em alguns casos, não é possível colocar os sujeitos em um determinado nível, porque eles, aparentemente, usaram diferentes modelos ao tratarem as situações apresentadas na entrevista. Esses sujeitos foram reunidos na categoria Misto. Todos os sujeitos que não tinham ainda estudado eletricidade e eletromagnetismo à época da pesquisa encontram-se nos grupos l e II. 


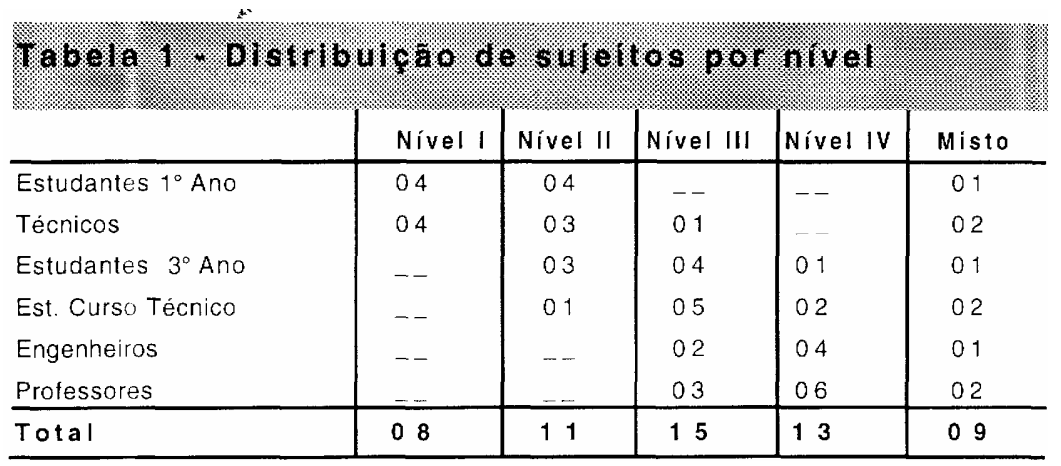

No nível l, as noções de eletricidade, energia e corrente não são diferenciadas, e magnetismo não é compreendido como sendo distinto de eletricidade. Os sujeitos, nesse grupo, usam esses termos para designar coisas que têm características de entidades e de conceitos. Tais sujeitos têm representações muito empobrecidas dos objetos envolvidos nas situações tratadas, e apenas aquelas características bem salientes destes são transpostas para os seus 'modelos'. Assim, não surpreende que as suas explicações para o comportamento dos sistemas não contenham referências a mecanismos internos que expliquem o comportamento dos mesmos. Ao contrário, o comportamento desses sistemas é explicado como resultado de suas propriedades intrínsecas. Nesse nível, os sujeitos parecem basear suas explicações em concepções específicas de cada situação. O conhecimento deles pode parecer incompleto e inconsistente.

No nível II, estruturas e entidades simples são supostas serem os

- Mudança na ontologia. Modelos mais elaborados introduzem novas entidades para explicar novos aspectos dos eventos num dado campo. Nos casos mais simples, o usuário refere-se aos objetos concretos com os quais ele lida. Progressivamente, ele introduz entidades invisíveis e abstraias para se referir aos fenômenos e eventos experimentados, mesmo que, muito freqüentemente, ele assuma que tais entidades existem de fato.

- Mudança nas formas de explicação adotadas. Modelos mais simples são puramente redescrições do que acontece baseado em aspectos salientes dos eventos e fenômenos observados, ou em atributos dos objetos envolvidos. Nos níveis intermediários, os sujeitos passam a levar em conta os outros objetos responsáveis pêlos fenômenos e eventos observados. Os sujeitos passam a considerar a contribuição dos outros objetos envolvidos na situação, mas os mecanismos envolvidos na produção deles são, em geral, implícitos e não existe uma idéia clara de interação. Por exemplo, a noção de atração entre positivo e negativo é usada como um princípio para explicar a interação entre imãs e outros materiais.

No nível III, já existe um considerável conhecimento acerca de processos e mecanismos internos e o foco é na interação entre os objetos envolvidos na situação. Explicações microscópicas são usadas em situações mais familiares, com preferência para modelos mecanicistas de eletricidade e magnetismo. Em geral, ao darem explicações ou descreverem o funcionamento de um sistema, os sujeitos descrevem uma seqüência temporal de eventos, o que sugere que estão fazendo uma 'simulação mental'. Os mecanismos que dão origem ao comportamento do sistema são mencionados explicitamente.

Finalmente, no nível IV os sujeitos podem adotar, conscientemente, diferentes modelos para explicar diferentes aspectos relacionados com um sistema ou fenômeno sob estudo. Por 
exemplo, sujeitos podem empregar modelos mais elaborados baseados em conceitos e noções abstratos, ou podem usar modelos do tipo que aparece no nível III. As interações diretas entre objetos são substituídas por interações que envolvem campos. Por exemplo, a interação magnética não é mais explicada como interação entre um imã e um objeto, mas como uma interação entre o campo magnético do imã e os dipolos magnéticos daquele objeto.

\section{Conclusões}

A posição, adotada neste estudo, é a de explicar um fenômeno ou sistema físico significa construir modelos mentais dele, que possam ser simulados na imaginação, para gerar explicações e descrições do comportamento e da evolução do estado do sistema. Quando deparam com um fenômeno, processo ou sistema novo, as pessoas formulam modelos iniciais, tomando algumas características daquilo que observam como ponto de partida. As propriedades que são escolhidas são aquelas que o observador considera relevantes naquela situação. Dependem, portanto, de como ele percebe a novidade, de seu conhecimento prévio e de memórias de experiências com situações que ele julga parecidas com a presente. Através do modelo, o observador estabelece vínculos entre as propriedades selecionadas, de forma a compreender o que é o sistema, de que ele é formado, como ele funciona e para que serve, entre outras possibilidades, dependendo de como ele percebe a situação.

Se a pessoa já tem algum conhecimento sobre o fenômeno ou sistema apresentado, sua percepção do que é relevante é diferente daquela do novato completo. Ela procura integrar aquilo que observa aos seus modelos anteriores, podendo dar origem a um dos modelos intermediários. O nível de sofisticação desse novo modelo dependerá, em última análise, da sofisticação de seus modelos prévios e da possibilidade de integrar o novo conhecimento aos seus modelos. Essa integração não é necessariamente acumulativa, podendo levar à formulação de modelos bastante diferentes dos modelos anteriores. Ela envolve a introdução de novas propriedades e a progressiva consideração da constituição do sistema e da interrelação entre suas partes, a introdução de novas entidades e a consideração de seus efeitos no comportamento do sistema. À medida que isso acontece, o sujeito tem que revisar seu modelo para adequá-lo ao novo estado de coisas que ele percebe.

Quando um estudante consegue revisar e enriquecer os modelos que usa para pensar e falar sobre um fenômeno significa que ele aprendeu a ver aquele fenômeno de uma outra perspectiva, que inclui novos elementos ausentes no antigo modelo. Portanto, qualquer estratégia de ensino deve ter como objetivo ajudar os estudantes na tarefa de construírem melhores modelos e deve considerar as dimensões ao longo das quais os modelos individuais evoluem. Assim, o vocabulário e as entidades usados para falar sobre o sistema devem ser explicitamente introduzidos. Da mesma forma, os estudantes devem ser auxiliados na construção de modelos mais ricos dos objetos e componentes que formam os sistemas que vão estudar. Isso pode ser feito, dedicando-se parte do tempo de aula para o exame mais detalhado tanto das partes que compõem o sistema quanto de suas propriedades e de suas inter-relações.

Se os estudantes não compreenderem esses aspectos relacionados com a estrutura do sistema, as relações entre estruturas e aprenderem a diferenciar os termos básicos do domínio, eles não conseguirão construir modelos produtivos do sistema ou conteúdo em questão. Tanto os professores quanto os livros-texto raramente são claros a respeito dos modelos que eles estão usando nas suas explicações. Um outro ponto, mencionado nas definições de modelo mental, é que diferentes tipos de informação podem ser exibidas num modelo, dependendo de seu propósito. Esses diferentes tipos de informação podem não ser importantes do ponto de vista de objetivos de ensino do professor, mas são essenciais para a construção de modelos mais detalhados dos objetos e sistemas que os estudantes devem aprender a explicar. Portanto, diferentes modelos precisam ser desenvolvidos para ensinar 
sobre um domínio, dependendo dos objetivos escolhidos pelo professor ou pelo texto. Tal aspecto tem recebido pouca atenção;

em geral, as mesmas analogias e representações gráficas são usadas, independentemente do contexto e dos propósitos.

\section{Referências}

ANDERSSON, B. (1986). The experiential gestait of causation: A common core to pupils' preconceptions in science. European Journal of Science Education, Q (3), pp. 155-171.

BLISS, J. (1995). Piaget and after: the case of learning science. Studies in Science Education, 25, 139-172,

BORGES, A.T. (1996). Menta! Modeis of Electromagnetism. Inglaterra: Universidade de Reading. (Tese de Doutorado).

BORGES, A.T. (1997). Um estudo de Modelos Mentais. Investigações em Ensino de Ciências [oníine]. Vol. 1, No. 3. Disponível pela Internet: $<$ http://www.if.ufrgs.br/public/ensino/>.

BORGES, A.T. \& GILBERT, J.K. (1998) Modeis of magnetism. Inter-nationa! Journal of Science Education. Vol. 20, No. 3, 361-378.

BREWER, W. (1987). Schemas versus mental modeis in human memory. In P.

Morris (Ed.), Modeiling Cognition. Chichester:

John Wiley. pp. 187-197.

CARROLL, J. M. (1991). Designing Interaction; Psychology at the HumanComputer Interface. Cambridge: Cambridge University Press.

CARROLL, J.M.; OLSON, J.R. (1988). Mental modeis in human-computer interaction. In M. Helander (Ed.). Handbook of Human-Computer Interaction. Amsterdam: Elsevier.

COLLINS, A. \& GENTNER, D. (1987). How people construct mental modeis. In D. Holiand \& N. Quinn (Eds.) Cultural Modeis in Language and Thought. Cambridge: Cambridge University Press. pp. 243-265.

CLOSSET, J.L. (1983). Sequential reasoning in electricity, In:

International Workshop of Research on Physics Education, 1, 26/06-13/07/83, La Londe lês

Maures (FR). Proceedings of the. First... Paris: Editions du CNRS. pp. 313-319.

de KLEER, J.; BROWN, J.S. (1981). Mental model of physical mechanisms and their acquisition. In J.R. ANDERSON (Ed.), Cognitive Skills and Their Acquisition. Hilisdale (NJ):

Lawrence Eribaum. pp. 258-310.

de KLEER, J.; BROWN, J.S. (1983). Assumptions and ambiguities in mechanistic mental models. In D. GENTNER and A.L, STEVENS (Eds). Mental Models.. Hillsdale(NJ):Lawrence Eribaum. pp.155-190.

DRIVER, R., LEACH, J., SCOTT, P. and WOOD-ROBINSON, V. (1994). Young people's understanding of science concepts:

Implications of cross-age studies for curricuium planning. Studies in Science Education, Vol. 24, pp. 75-100.

DUIT, R., JUNO, W. and RHONECK, C.V. (Eds.) (1985). Aspects of Understanding Electricity. Kiel, Germany: IPN.

GENTNER, D. and GENTNER, D. R. (1983). Flowing waters or moving crowd: Mental models of electricity. In D. GENTNER and A. L. STEVENS (Eds.), Mental Models. Hilisdale, NJ:

Lawrence Eribaum. pp. 99-130.

GENTNER, D. and STEVENS, A.L. (1983). Mental Models. Hilisdale, NJ: Lawrence Eribaum. 
GIERE, R.N. (1988). Explaining Science: A Cognitive Approach. Chicago: The University of Chicago Press.

HAUPT, G.W. (1952). Concepts of magnetism held by elementary school children. Science Education, 36, pp. 162-168.

HAYES, P.J. (1985). Naïve physics 1: Ontology for liquids. In J.R. HOBBS \& R.C. MOORE (Eds.) Formal Theories of the Common-sense Worid. Norwood: Ablex Publishing Co.. pp.71-107.

JOHNSON-LAIRD, P. (1983). Mental Models. Cambridge, MA:

Harvard University Press.

MAYER, R.E. (1989). Models for understanding. Review of Educational Research, 59 (1), pp. 43-64.

MAYER, R.E. (1992). Knowledge and thought: Mental models that support scientific reasoning. In R.A. DUSCHL and RJ. HAMILTON (eds.) Philosophy of Science, Cognitive Psychology and Educational Theory and Practice. Albany (NY): SUNY Press. pp. 226-243.

OSBORNE, R. (1983). Towards modifying children's ideas about electric current. Research in Science and Technology Education, Vol. 1 (1), pp. 73-82.

PAYNE, S.J. (1991). On mental models and cognitivo artefacts. In Y. Rogers, A. Rutherford \& P.A. Bibby (Eds.) Models in the Mind. London: Academic Press. pp. 103-118.

PIAGET, J. and GARCIA, R. (1989). Psychogenesis and the History of Science. New York: Columbia University Press. 
